\title{
Analysis of Social Policy Commitments in the Election Manifestos of the Justice and Development Party: $2002-2015$
}

\author{
Nergis Dama' 1 (1)
}

\begin{abstract}
The opinion that social policy implementation affects voter behavior has caused political parties to include social policy commitments in their election manifestos. Given the perception that social policy has an impact on voting behavior as well as economic and political anticipation, social policy is included in election commitments. In this study, the social policy commitments of the Justice and Development Party, which has been in the lead of general elections held during the period 2002-2015, have been evaluated using content analysis. The research sample includes only social policy commitments in the election manifesto. The aim of this study is to investigate the social policy commitment of the Justice and Development Party and to explain the alteration of the social policy perceptive and the implementation of social protection. In this way, the study attempts to explain the social policy approach of the party.
\end{abstract}

\section{Keywords}

Social Policy, Election Commitment, Social Protection, Political Party

1 Corresponding author: Nergis Dama (Asst. Prof. Dr.), Ankara Yıldırım Beyazıt University, Faculty of Political Sciences, Department of Economics, Ankara, Turkey. E-mail: ndama@ybu.edu.tr ORCID: 0000-0002-8210-254X

To cite this article: Dama, N. (2021). Analysis of Social Policy Commitments in the Election Manifestos of the Justice and Development Party: 2002 - 2015. Journal of Social Policy Conferences, 81, 501-536. https://doi.org/10.26650/jspc.2021.81.908781 


\section{Introduction}

Since the 1946 general election in Turkey, often acknowledged to be the beginning of democracy in Turkey through the adoption of the multi-party system, there have been 27 parliamentary elections. After this date, despite attempts to fully implement democracy, efforts to establish democracy were disrupted by coup d'états, coup attempts, and covert coups. The dates of the abovementioned coups d'états and coup attempts (May 27, 1960, September 12, 1980, February 28, 1997, April 27, 2007 and July 15, 2016, respectively) show that elections and coups follow one another in Turkey. Although it is considered usual to have elections in the wake of political and economic crises, elections that follow a coup, under the shadow of military forces, were also accepted to be customary in Turkey. Despite this acceptance, five general elections, generally viewed as the reflection of the people's will and as the most effective democratic instrument in Turkey, were held between 2002 and 2015. These elections are the general elections on November 3, 2002, July 22, 2007, June 12, 2011, June 7, 2015 and November 1, 2015. Although each election entails different dynamics, the fact that voter turnout was high in each proves that the voters of Turkey staked a claim to their right to vote and put great importance on it. Chart 1 shows voter turnout and the number of votes cast in the abovementioned five general elections. Accordingly, except for the 2002 elections, voter turnout in general elections in all the years stated was above 80 percent. The number of voters in Turkey is higher than half of the population due to its dense young population, as the voting age in Turkey is 18 . The number of votes cast per year shows the importance given to elections by the voter population. 


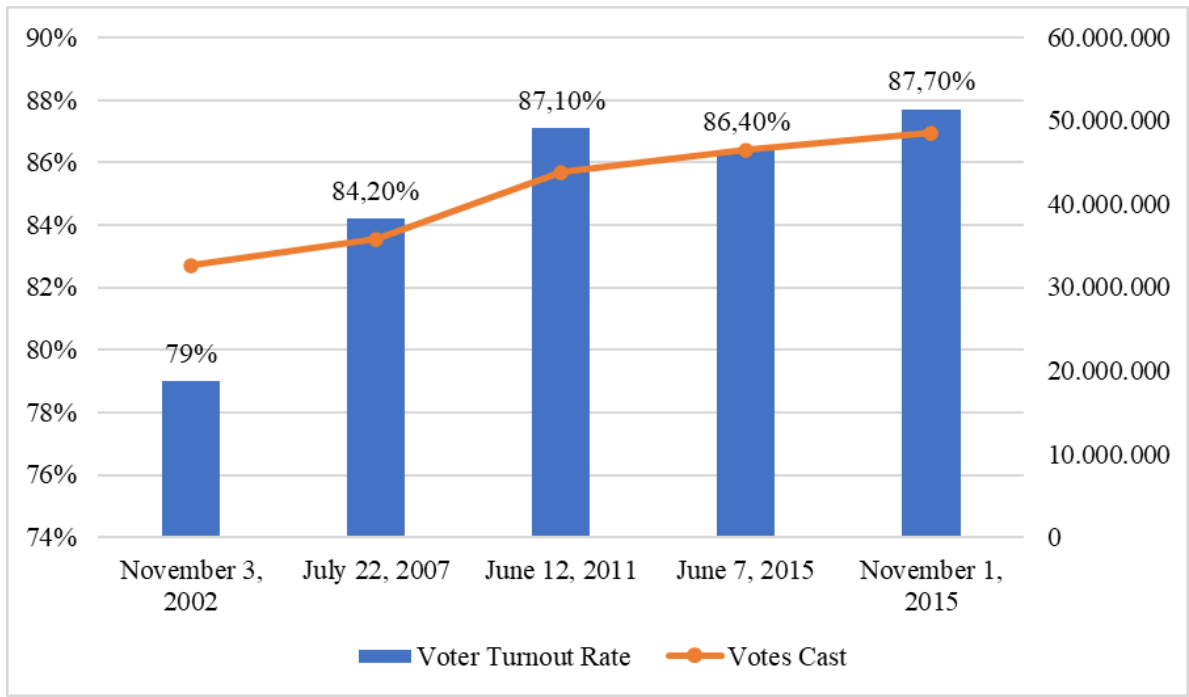

Chart 1. The Number of Votes Cast in the General Election Period of 2002-2015 (in Millions) and Voter Turnout Rate (\%)

Source: Supreme Election Council, 2019. ${ }^{1}$

High voter turnout can be seen as the reflection of the desire to have a voice in what will define the political power that will, in turn, form the administrative staff. It can also be seen as appreciation or criticism of the former practices of governments, and voters expect that the election will lead to the implementation of their will in the future.. There are many factors that influence voter behavior, such as economic, political, sociological, cultural, etc. factors. The representatives of political parties are then forced to develop their discourses and policies based on these variables to define, change, and manipulate the voter behavior which is rendered concrete after the voting. Following the general election held on November 3, 2002, social policy practices began to be included by the parties, in the respective fields that were influential on the voter behavior. Since social policy commitments correspond to both economic and social gains, these commitments also correspond to the economic and sociological dimensions of the factors that have an impact on the voter behavior.

This study analyzes how the acknowledged impact of social policy commitments on voter behavior is reflected in the election manifestos. Therefore, the social policy practices that were committed in the five general elections of the highest rated party in the general elections were studied within the scope of 2 themes, namely the social policy understanding and the social protection.

1 Retrieved from: http://www.ysk.gov.tr/tr/milletvekili-genel-secim-arsivi/2644 
In this study that attempts to understand the approach of the ruling party in the field of social policies through its social policy commitments, the goal is to contribute to the social policy literature with the evaluation of the development of social policy discourses of the Justice and Development Party (JDP) within a 16-year period. The main goal of this paper is to analyze the party-based development and the transformation of the social policy commitments disclosed prior to five general elections.

\section{Literature}

Before each election, election declarations published by political parties contain promises that will increase the socio-economic well-being of citizens. These declarations constitute the source of the discourses to be used in election campaigns. In order to persuade voters and to direct their vote preferences towards them, election manifestos state what the politicians will do when they have power over different topics. The publication date of these documents also reveals the election vision of the party for that year. Compiling and examining the panel data according to election year is important in terms of showing the change in the election promises of the parties over time. Beyond determining voter preference, this data source was used as regards the change in the social policy promises of JDP, which is the subject, over the years.

Although the promises and commitments in the election declarations belong to that election year, they are also binding for the next election. The election manifesto is an important criterion for determining the extent to which the political, social and economic goals promised to the electorate have been achieved (Beriş, 2011). Research has been conducted on the issues to which political parties give priority in their election manifestos and whether the weight of these issues in the declarations changes according to the election years. In the 2002, 2007, 2011, 1 November 2015 and 2018 presidential elections, the parties focused on four main themes: democracy, economy, social life and culture/technology. These were included in their election manifestos. In the same study, it was determined that the importance given to these issues by the parties in different election dates changed. In the field of social policy, which is also the subject of this study, National Movement Party (MHP) allocated more space in 2002, Republican People's Party (CHP) in 2007 and 2015, and JDP in 2011 and 2018 (Çatı and Cengiz, 2019). 
A study examining the election manifestos of the parties that adopted the right-wing political approach in the Turkish Grand National Assembly (TBMM) during the 1950-2018 period focused on whether the election discourses changed on a yearly basis. Accordingly, while right-wing political parties prioritize promises about freedom, democracy, political system, economy, welfare and quality of life in their election manifestos and promises are determined by categorizing socioeconomic groups. One of the distinguishing features of the study is that the discourses in the election declarations change with respect to the election periods and also the priority policy areas differ (Torlak and Tiltay, 2021). Research has also been conducted on certain topics in the election manifestos. In the study, in the election manifestos of the parties that had the right to form groups in parliament after the 7 June 2015 election, the frequency of use of the concept of disability and promises for the disabled were evaluated by content analysis. Accordingly, it has been found that the party that uses the concept of disability the most and has the most promises for this group is CHP. Promises in the fields of socioeconomic policies, education, health, and employment have quantitative superiority in declarations (Sagın and Gümüş, 2016).

In another study, in which the election declarations of the 5 parties with the highest votes in the 31 March 2019 local election were selected as a sample, it was determined that the declarations were different in terms of form and content. In the field of local government, the promises made have similar characteristics despite the different ideologies of the parties (Arklan and Tanac1, 2020). In the election of 24 June 2018, it is seen that technological and digitalization policies are used to influence voters in the election manifestos of the parties (Alp and Turan, 2018). In the document analysis made on the sample of the election declarations in the general elections of 12 June 2011 and 7 June 2015, the change of the political parties in the two elections was examined according to the election promises in the election declarations. Accordingly, while there is no difference in the economic promises of political parties, it has been determined that they show changes in social life. While the CHP gave more place to the welfare state in its promises, the MHP focused on the promises on law and terrorism (Özkaynar, 2015). After 1990, parties included more environmental issues in their election manifestos and subheadings on the environment increased quantitatively (Şeşen and Ertürk, 2017). 
It has been argued that the social policy promises in the election manifestos and the implementation of these promises affected the vote rate of the political parties positively and were effective in the AK Party's ruling after 2002. In the 2000s, supporting these individuals who are outcast from economic and social life due to their vulnerable or poor socio-economic characteristics caused the embellishment of the practices in this field. It is argued that the ruling party became the first party in the general elections between the period of 2002-2015 because of these social policy practices. Based on this inference, an argument posited is that the ruling party defines the social state identity according to its politics and economics, and that its characteristic as a conservative party helps develop social policy practices over welfare (Koray, 2015). It is also argued that especially social aids are used for political demands, and through this, a dependent relation between the citizen and the party is formed (Urhan and Urhan, 2015). However, in 2011, the social policies that are claimed to form an efficient vote pool for the party have achieved an institutional structure by the establishment of the abovementioned Ministry, and they became state policies independent of the party. In addition, the social assistances were incorporated into the Ministry, and the criteria to benefit from social assistance were based not on party membership, but on the socio-economic needs criteria. Yet, it is also stated that the social assistance, an instrument considered to be the first resort in fighting poverty, comprises a temporary solution, and that the social assistance increased in Turkey in the 2000s - charity being the basis of this practice (Güneş, 2012).

Within the social security system, another dimension of the social protection, the transformation in healthcare and General Health Insurance policies was taken into practice as a solution to the low rates in access to healthcare services and the low quality of these services, which constituted serious problems until the 2000s. The practices that are observed to have a positive impact on the election results of JDP are deemed successful since they offer access to health services for the poorest individuals of society. While the quantity of the services is observed to be adequate, there are still criticisms that argue that this reform narrows down the rights to social security (Kapar, 2015). This thesis is based on the idea that the social policy understanding of JDP causes clientelism, and in turn, social protection practices cause a dependency relationship. The thesis in question bears the argument that there is a correlation between the social policy commitments and the election success. When social protection, which is comprised of social security, social service, and social assistance practices, 
is taken into consideration, the criticism that JDP implements social protection through -in particular- the social assistance forms the basis of the inference that these are the sole basis of the social policies of the JDP period. In such arguments, these practices are coded as "the mercy economy", indicating that the conservative structure of the ruling party defines its approaches to social policy based on Islamic rules. It is also argued that the social policy practices in the party program are defined by adopting a conservative approach (Altiok, 2007). Yet, the commitments in the election manifestos that overlap with the social democrat welfare regime practices are quite high in amount.

Therefore, what is experienced is a transformation between the "rights-based social policies" understanding and the charity understanding. One of the prominent issues in this debate is that the welfare for the poor should be taken out of the context of "charity" and should be offered based on the principle of "rights." The argument that for the ruling party, the social assistance is instrumental to influence voter behaviors causes this field to fall not just within economic and social policies, but also within the agenda of the current politics. It is also claimed that Justice and Development Party prioritizes social assistance as a social policy understanding to enable the capital owners gain privilege (Durmaz, 2016). Also, it is argued that despite having adopted a market-based economic policy, JDP receives strong support from poor communities, that the reason behind this support is the irregular clientelist social policy practices that are not distributed based on criteria of rights. In turn, they influence voting behavior (Çelik, 2010). When the rationale that the poor citizens shall vote based on their social and economic gains - just like other individuals with strong socio-economic indicators- is ignored, this causes the voting behavior of the low and middle income and upper income groups to be evaluated hierarchically. According to this understanding, the voting behavior of poor citizens is defined by the social policies that they benefit from. In this view, whereas the economy, domestic policies, foreign policies, education, and security policies that can influence the voting preference of the citizens in elections are interpreted as the concrete indicators of the likes, appreciation or criticisms of the citizens to the politicians, voting based on social policies is interpreted as voting based on interests. On the other hand, a study, based on sampling from the province of Elazığ, Turkey, has found out that the commitments of the parties regarding economy and employment have priority over the social assistance -their social policy practices- in the voters' political preference (Doğan, 2016). 
Expansion of the scope of social policies in the election commitments supports the view that the parties which are candidates to become the government adopt the belief that they will gain votes through these commitments. The voters give power to their political representatives through votes for the commitments in the party plans and programs that are to be realized (Sakal, 1998). While they may learn these commitments from realized meetings and pamphlets or booklets distributed throughout the election campaign, they may also learn them from the manifestos that contain all the commitments also issued prior to the elections. The voter behavior is influenced by their belief in the policies committed to be implemented by the party representatives (Özsoy, 2002). Therefore, the election manifestos that contain these commitments can be considered as a publication aiming at influencing voter behaviors.

Since characteristically the target audience of social policies are fragile groups, the commitments in this field are of interest to the communities that require the state support by social protection. The individuals who are insufficient socially or economically by birth or through later conditions require state protection to access welfare services. Although they may vary in the socioeconomic aspect, each and every individual has the same and equal rights in voting, thereby the social policy commitments gain importance in receiving the votes of the fragile communities of a society. The studies on how voting behavior is defined or changed assert that persons vote the parties who are close to their ideologies and that they vote pragmatically according to the practices or commitments that have an impact to their material wealth (Gökçe, et al., 2002). Thus, benefitting from welfare services equally and fairly, i.e., from services, such as education, health, employment, social protection, etc., influences voter behavior. A study of Gaziantep province, Turkey, reveals that the variable that has the most impact on voter behavior is the services provided for the people (Tan and Baydaş, 2017). This situation increases the importance of social policies to be offered to the disadvantaged communities that experience issues in accessing to and benefitting from these services.

One of the reasons why JDP became the first party in the elections of the post-2002 period in Turkey is thought to be the social policies that were implemented for the disadvantaged groups. The political and economic commitments of JDP based on the fair and equal access of low- and middleincome group voters to public services, such as education, health, transportation 
etc. and based on fair distribution of income was supported with social policies. The disadvantaged groups that are the target group of social policies have positioned JDP as the central party for the support it provided to the social policies and the improvements it has achieved in the fields of politics and economics (Özipek, 2011). This situation supports the view that the commitments to social policy have been accepted by the voters, and this acceptance has transformed into votes for the party. Since consequently JDP has structured the social protection in a generous and inclusive manner, this reflects that JDP has also accepted the view that it has won the trust of the voters through social policies.

\section{Theoretical Framework}

Political parties use election manifestos as texts to reach voters and declare their promises to them. These documents provide an idea of what kind of roadmap the parties will follow in the country's administration if they accede to power after the election. The declarations, which are important in terms of informing the voters, contain promises used to influence the vote choice of voters. Party program and declarations are written texts that show the commitments of parties to do if they have the power to govern (Bulut and Güven, 2010). Election declarations do not only provide a perspective for the future policies of parties, but these documents are also used to monitor the changes in the political approaches of the parties according to the election years (Naurin, 2011; quoted in Şeşen and Ertürk, 2017). For this reason, the change in the attitudes of the parties on social and economic issues over time can be examined by reviewing the policy discourses and promises in the election manifestos.

By analyzing the promises under different topics in the election declarations, the approaches of the parties to the same issue can be compared. In addition to making comparisons under macro headings, such as economy, employment, education, health, transportation, housing, etc., election manifestos are an important data source in order to examine the promises for different socioeconomic groups. There are studies on the approaches of the parties to themes such as the environment, technological development, gender, poverty, and social assistance. Additionally, the research subjects that are selected are women, the young, the disabled, the poor, the elderly, etc. Examination of the 
discourses of the ruling party and the main opposition party towards women (Terkan, 2013), the approaches of the same parties on gender inequality in their election manifestos (Ekici and Acar, 2017), the policy priorities of the political parties in the election declarations of the 2002-2015 period (Aytaç, 2017), and education policies (Tok, 2012) are focused on in the previous studies. In addition, election declarations were also used in studies examining the change of parties over time (Aydoğan and Slapin, 2015). The results and findings of these studies show that the speeches and promises used by political parties in election manifestos are an important data source for comparisons both in the current election period and in the future.

Election declarations, which are a written document, are an important source to refer to in terms of which promises to stand out during election periods, the priority policy areas of political parties, and the change in their approaches according to election years. JDP, which was the first party in all general elections held after 2002, is the first actor to shape Turkey's social policy structure in the 2000s. Therefore, the examination of the social policy approach in the party's election manifestos reveals the change in the social policy vision of the party over the years. It also provides a perspective on social policy implementation priorities in Turkey.

\section{Method}

This study adopts the qualitative research method and case study approach, forming a qualitative research pattern. Case study offers a qualitative research pattern in which one or more cases within a certain period are analyzed through multiple data gathering tools, such as observation, interviews, documents and reports, and allows to define themes depending on the cases. Taking into consideration five general elections realized within the 2002-2015 period, the data pertaining to social policy commitments of the party with the most votes prior to these general elections are procured through document analysis. Document analysis is the method in which materials containing the data pertaining to the research subject are parsed (Gürbüz and Şahin, 2014). Election manifestos are chosen for this study since the aim is to analyze the social policy commitments prior to elections. The manifestos are retrieved from the website of the party with the most votes. Since they are public documents, there are no issues regarding their use. 
The purpose of this study is to analyze the social policy commitments of the party with most votes in five general elections, taking into consideration the assumption that social policies influence election success. The commitments received from election manifestos through typical case sampling are compiled under the headings of "social protection" and "social policy understanding." Typical case sampling method entails data gathering in accordance with the principles of information gathering on a specific case using samples. In this study, social policy commitments explain the case, and social policy understanding and social protection commitments are chosen as the typical case. The validity of the procured data is described in a manner that suits the predictive validity. The data and interpretations are checked by 2 researchers using direct quotations from data sources and data triangulation. Thereby, data coherence is achieved.

The data procured based on the themes of "social policy understanding" and "social protection" defined during data analysis are further subjected to descriptive analysis method. The social policy commitments used in five elections are categorized under 2 themes per election year. The headings of social policy understanding, and social protection form the conceptual framework of the descriptive analysis. For an analysis of the commitments under these headings, the social policy commitments of five general elections were categorized according to the election years, and also, the respective categories are in turn defined according to election year in question.

\section{Research Findings}

In this study, primarily the social policy commitments present in JDP's election manifestos for five elections are analyzed. Social policy issues are categorized in 17 codes (poverty, welfare, income equality, unemployment, discrimination, employment, social protection, equal opportunity, social assistance, social service, social security; and according to the target audience of social policy practices, namely: the poor, women, youth, children, persons with a disability and the elderly). Following the coding, 4 further categories are formed, which were, in turn, transformed into 2 major themes. These are the social policy commitments aiming at the social protection system, namely social policy understanding, social assistance, social service, and social security. 
Social policy commitments in the election manifesto of JDP disclosed to the public prior to the general election held on November 3, 2002 were listed under the heading of social policies. These commitments do not just offer an economic development goal related with the economic conditions of the period, but they also express an approach in which economic policies are in conformity with the social policies. This situation shows a commitment to the low- and middleincome groups who have experienced a serious economic crisis in 2001 and who have shouldered this crisis' cost that the social justice shall be realized alongside the economic development.

"Economic development policies shall be implemented in a manner in balance with the social policies."

"Placing 'human' to the center of the economic development is a 'moral' obligation for enhancing income distribution and for the success of the policies that aim at fighting poverty."

It can be said that by implementing social policies, JDP aims at winning the trust of the citizens who have lost their trust due to the economic crisis, and therefore, that JDP considers economy in conjunction with the social policies. So, instead of an understanding that posits economy policies should be prioritized since social policy practices are to be accepted as costs, the manifesto states that economic program should comply with social policies. This situation is foregrounded as a commitment for the low- and middle-income groups who have felt the impact of the 2001 economic crisis that the goal of ameliorating the economic condition shall be realized without any cutbacks in social policies.

"In economic program and policies, 'social justice'shall be guarded, and a new development approach that places "human" to the center shall be adopted."

Another commitment analyzed in the manifestos is regarding the social protection instruments, namely social security, social service, and social assistance. These codes are placed under the theme of social protection system. These commitments promise that everyone shall be included in the social security, and they underline that social security is an insurance against present and possible social and economic risks and that it shall be available for all citizens whatever their socioeconomic statuses in the society may be. The 
commitment that employment or bonus clauses shall not be decisive to benefit from social security and that the poor and the needy shall be covered under the roof of social security assumes that this will define the voting behavior of the low- and middle-income group voters in Turkey.

"Social security net shall be expanded and the welfare institutions that provide services to the poor communities will be restructured."

"A General Health Insurance System that encompasses the whole population shall be established to, and the premiums of those without the means to pay them shall be paid by the state.'

In 2007, social policy commitments were provided in the chapter titled "Strengthening the Social Structure, Expanding Employment and Life Quality." In contrast with the 2002 manifesto, the 2007 manifesto is a text that for its majority offers a recount of the past accomplishments instead of commitments. The categories that fall under the categories of social policy understanding and the social protection system highlight, respectively, the prerequisites of a social state identity and the transformation of the social security system. The term that was most underlined in the social policy understanding of the 2007 election manifesto was the term "justice." All practices of the five-year term following 2002 were explained with a rationale that the principle in motion was a fair distribution of wealth.

"Our basic principles in our policies are providing a response to the justice and development demands of our people and bringing forth the choices of our nation into politics."

"The most basic concern, the ultimate goal of our party and our understanding of government is to guard social justice in the distribution of the opportunities of our country and social wealth and to realize the social justice."

In the social policy understanding section of the manifesto, the commitment is that the party adopts "social state" practices. Even though the Justice and Development Party has a conservative party identity, its social policy commitments display the characteristics of a social democratic welfare typology. Also, pointing out that the impact of the 2001 economic crisis is diminished, the party commits to ensure that each and every citizen, irrespective of their socioeconomic status, shall benefit equally and fairly from economy and social 
assistance. However, as of the date, the positive indicators such as the decrease in poverty rates and the increase in income per capita has not been reflected to the fair distribution of income. The social policy understanding based on the idea that each citizen should benefit from economic and social wealth, without any discrimination has been often underlined, all the while mentioning the concrete practices realized within the period from 2002-2007. In order to receive voters' support, the low- and middle-income group voters who have been the most affected group from the economic problems and inequality of opportunity were offered the promise that the party has adopted the social justice principle. In addition, the social justice understanding was associated with the "social state" characteristic, and the commitment that, by force of the social state, citizens shall not suffer the loss of their rights. This condition has been rendered concrete in the commitment that each citizen shall be ensured to have fair access to rights, opportunities, and services. Another discourse of significance in the manifesto is present in the phrase indicating that citizens shall not feel desperate and vulnerable via social policy practices. In the manifesto, this is phrased as "Attending the Unattended" or "Caregiver to the Outcast" that became one of the basic concepts of JDP's social policies in its later terms.

"The importance we place on the social policies shall continue in a more elaborate manner in the coming term. We commit to our full political will to let our citizens experience in their daily lives the principle of 'Social State,' expressed in our Constitution in all its dimensions. We shall maintain our basic goal to realize the ideal of 'social justice', in particular, the income distribution and living humanely dimensions of the concept of 'justice' that we bear in the name of our Party."

"The income distribution, having entered a recovery trend in the term of our government, shall be more balanced, the net of social security-social assistancesocial service shall encompass all our citizens with a centralized organization and the services that we believe to be the basic human rights, such as education and health, shall attain a more contemporary identity."

From the aspect of social protection system, and in contrast with the 2002 election manifesto, the 2007 manifesto contains an extensive chapter on the practices realized in the period of 2002-2007. The commitments in this field are focused on social security, and it can be seen that the social security reform is foregrounded more with respect to social assistance and social services. The 
direct relation of healthcare service with the status of a person in the social security system in Turkey causes healthcare and social security, or in other words, the basic public welfare system to be assessed together. The commitment to offer fair service in healthcare, also rationalized by the social policy understanding of JDP, was rendered concrete with the General Health Insurance (GHI). In the social policy commitments section of the manifesto, the reason why the practices that had become laws were not realized was stated to be the repeals by the Constitutional Court. The manifesto also addresses the importance of GHI for the children below the age of 18 and for the poor citizens benefitting from the fair and high-quality healthcare services. At this point, another commitment is made that GHI shall become the solution that prevents the problems experienced by poor citizens benefitting from healthcare services. When JDP becomes the ruling party following the election, each and every article of the GSS shall be implemented.

"One of the most important projects of JDP, included in the Emergency Action Plan, is the 'General Health Insurance': the system in which all our people, without discriminating for the poor or the rich, shall benefit from healthcare services with the same standards, in which the premiums of the poor shall be covered by our state, and in which all our children under the age of 18 shall benefit from health insurance. This system had to be postponed despite being accepted by the GNAT and issued as a law since some of its articles were repealed by the Constitutional Court. Yet, we are determined to implement this system until 2008."

"Within this scope, we are determined to realize all aspects of social security reform that has been in the agenda of our country for approximately 45 years."

In the 2007 election manifesto, the issue of retirement, along with healthcare services, is treated in detail within the commitments under the social security system heading. Retirement is an often-referred commitment subject during election periods. One of the most known commitments that causes serious issues in the social security system is the right to become a pensioner within the ages of 35-45 that was due to the removal of the age limit for retirement in the 1991 elections. Even though this right has provided great contributions to the beneficiaries, it has caused a very serious harm to the financing of the social security system in Turkey, and therefore to its sustainability. In the 2007 election manifesto, it has been expressed that the problems and inequalities caused by 
the past practices shall find their solutions through social security reform. However, it is of note that it has been expressed that the acquired rights, used as an election commitment for many years and a heavy burden on the system with increasing costs, shall be protected in this reform. This situation shows that the prevalent understanding is that cancelling out the previous election periods' practices, in order to influence the voting behavior, shall result with loss of votes. So, the party commits that the retirement rights of the present workers shall be protected and underlines that this is an acquired right.

"The age to earn the right to retire, premium payment and insurance terms of the present workers (their acquired rights) shall be protected exactly, and a retirement regime that ensures an equal and fair service to all our citizens shall be formed.'

Another commitment states that the unity of norms aimed at with the social security reforms shall be realized without causing any harm to the acquired rights of the currently insured. These two commitments show that one of the most important variables that influence the voting behavior is the promise regarding retirement rights. Instead of offering a commitment to end these practices without any rationale, the commitment is for an equal and fair system for those who will recently enter the system, while preserving the acquired rights.

"The pensions of the present workers shall be calculated based on their term both in the old system and the new system. Thereby, the currently insured shall be transferred to the new system gradually, within a long term, ensuring norm unity without causing the victimhood of the currently insured."

Regarding the social assistance, it is seen those commitments on creating a database are foregrounded. According to this commitment, a software system is promised in which data required to benefit from social assistance shall be preserved, and if according to this data, a person is below poverty line, that person shall earn the right to benefit from social assistance. Despite the criticisms that social assistance-vote relationship is clientelist, ideological and not based on rights, the manifesto states that the social assistance system to be established will be demand-based and will work according to certain criteria. It can be said that this commitment that the database shall work in coordination with the social security system is constructed to form the relationship between employment and social assistance. 
"Address-based Population Registration System that also contains the income status and livelihood conditions of our people shall be combined with the operations aiming at inventory and poverty profile designation that are formed within the scope of social assistance and solidarity. The central information system formed in this manner shall provide a collective look especially at our population covered under the scope of social security."

This commitment in the manifesto regarding the provision of social assistance, with a focus on rights and in a systemic manner, also contains the continuity of social assistance. The systematic structure that will be attained in the social assistance system by the formation of a database reveals that it shall prevent wrongful and unfair use of social assistance, yet the understanding that social assistance is a right shall be sustained. Social assistance is one of the most efficient tools for the practice of meeting the needs of shelter, food, fuel, and education of the low-income groups. The accepted view that social assistance has been implemented in a "rights-based" manner since 2002, and that this practice has a positive impact on the voting behavior, caused the social assistance to keep its designated place in the current election manifesto.

"In the coming government of the Justice and Development Party, it shall continue its social assistance and support policies, with more strength within a novel structure. The inventory and information system that is substantially complete shall become stronger with the Address-based Population Registration System that is about to be completed."

In the election manifesto prepared for the general election to be held on June 12,2011 , after the 10-year government term of the 2002-2011 period, the social policies are provided under the heading of "Strong Civil Society." 2011 manifesto is different from 2002 and 2007 manifestos in that it contains the detailed recount of the 9-year period and the goals of Turkey as a social state, setting the year 2023 goals as its basis. As in 2007 election manifesto, the deeds in the past 4 years were foregrounded in 2011 manifesto. While the present practices were explained in detail, the commitment is that these practices shall be developed in accordance with the 2023 goals. The common emphasis in the commitments is the theme of "equal opportunity," as it was so in the 2002 and 2007 manifestos. "Equal opportunity" was also emphasized in the social policy understanding, and it was expressed that positive discrimination practice shall be called upon to ensure equal opportunity. Despite the criticism that positive 
discrimination shall deepen the inequality faced by the disadvantaged individual/ group, Justice and Development Party commits to ensure equal opportunity through positive discrimination.

"At the foundation of all these services is the effort to ensure justice, wealth, quality of life and equal opportunity."

In the manifesto, social policy understanding of JDP is that each and every citizen shall have equal and fair access to public services and shall feel as equal citizens. The phrase stating "preventing discrimination and ending unfair practices" often resorted in the election manifestos suggests that the social policy philosophy of the party is based on the principle of justice. The commitment is that no socioeconomic status shall cause any form of discrimination in receiving services, and this condition found its place in the commitments as the basis of social peace and solidarity.

"We shall not discriminate against our people, whatever their financial condition may be, and we shall continue considering everyone as first-class citizens."

There is a serious criticism in the manifesto against the characterization of the social assistance provided to the poor citizens, especially in the election periods, as "almsgiving." Underlining that providing social assistance to needy citizens is the duty of the state and that there is no need for citizens to feel grateful to the state, social assistance is defined as a "right" in the manifesto. This situation forms the basis of the view that disregards evaluations on party-based social assistance and regards social assistance as the duty of the social state.

"The compassionate hand that has reached out to low-income families and individuals during our government's term has been called by our opposition as 'an almsgiving culture', whereas 'almsgiving' refers to an act of charity that comes out of a person's own pocket. The state does not distribute alms to her citizens, she provides social support as a right. And it is out of the question that our people should feel "gratitude" to the state. The people should feel 'satisfied' when the state does her duty, not 'gratitude'. That is because democracy is based on the satisfaction of the citizens, not on their gratitude."

The target audience of the commitments reveals the people that the Justice and Development Party defines as the disadvantaged groups. This group, stated 
to be the poor, disabled, elderly, orphans, veterans and relatives of the martyrs, in its turn, gives its name to the respective directorate general with the institutionalization of the social policies at a ministerial level.

"A state that does not see, protect, look after and watch over and protect the low-income individuals, persons with a disability, elderly people, widows, orphans, veterans and those trusted to her by her own martyrs cannot be a social state."

Regarding the social assistance, the 2011 election manifesto, in contrast with the other manifestos, commits to increase the efficiency of the social assistance. Along with the commitment to increase the provided social assistance, the manifesto states that these aids shall not be enough to provide a permanent solution and that the social assistance beneficiaries shall be supported with education and employment. As a goal, it has been stated that instead of social assistance, the term "social support" shall be used, and that the needy citizens shall be included in the production in the country. However, the term "social assistance" was widely accepted and did not leave its place to "social support." This condition supports the idea that social assistance was still at the time a temporary solution and the beneficiaries were not still part of the work life. As a matter of fact, in both elections held in 2015, not the term social support, but the social assistance was used.

"In the coming term, we shall again resolutely implement our social assistance' program that aims, on the one hand, to stand by the low-income groups, and on the other, to transform these groups into citizens who can stand on their own feet, with the understanding that poverty is a temporary situation."

"We shall establish a social support system in which social support and services are offered in integration and based on rights."

"We shall provide all forms of support to the poor citizens who are available to work but are not employed to render them productive individuals who can stand on their own feet."

"In 2010, we have implemented Action Plan to Render Social Assistance System Effective and Connected with Employment. Within the scope of this action plan, our efforts to transform our poor citizens who are able to work, but are not employed, into individuals who can stand on their own feet shall 
continue in the coming term as well. While these persons shall be provided with job search supports and occupational training, they shall also be provided with welfare until they find a job that can enable them to become sled sufficient. Therefore, these groups shall both receive social support and be prepared to the labor market."

In the social protection system commitments of the manifesto, it is suggested that JDP observes social security as a basic right and that social security shall be more inclusive. Since social security in Turkey is coded as benefitting from retirement and healthcare services, the commitments in these two subjects are foregrounded. Again, the common characteristic of the commitments is that their target audience is the low- and middle-income group. The idea that lacking healthcare services due to material deprivation is unacceptable and that the poor citizens should have access to healthcare services and benefit from them is presented as the prerequisite of a social state. In addition, there are commitments aimed at financing the social security system for it to continue its characteristic of inclusivity in the future. The common goal of these commitments is suggested to be the transfer of the right to social security and the practices in their current state to future generations.

A commitment different than others in the manifesto is related with single parent mothers. This commitment suggests the view that Justice and Development Party, characterized as a conservative party that adopts a family centered social policy understanding, adopts policies that conform with the social democratic typology. The commitment states that single/lone parent women shall be provided with housing support so as to keep them by their children. Contrary to the traditional housing type in Turkey, it is stated that studio houses shall be provided as a shelter space, and the women shall receive social support as well.

"In order for lone mothers who live with their children to live their lives more securely and healthily without being separated from their children, we shall provide every social support, alongside 'studio houses'prioritized to shelter them."

The commitments related to women are focused on employment and childcare incentives. When that women's contribution to workforce in Turkey is at a low rate and that the family's and children's responsibilities are the primary causes of withdrawing from work life are taken into consideration, it can be said that the aim of these commitments is both to protect family structure and to prevent 
the loss of labor force. This understanding is within the scope of conservative welfare regime since it is family oriented, and it is within the scope of social democratic welfare regime as it aims at increasing women employment. Despite the fact that Justice and Development Party represents right-wing and religious electorate, its social policy practices display a hybrid characteristic. This situation shows that despite the fact that social policy understanding in Turkey was constructed by a right-wing party, both the conservative and the social democratic welfare practices are implemented together, contrary to the typically attributed welfare typology to such a party. Similarly, the supports provided for schooling girls reveal that the ruling party implements a positive discriminatory practice based on gender for its social policy target groups.

"In order to ensure our registered working women to keep their employment status, we shall provide childcare and education incentives to our women who are sending their children to kindergarten. Thereby, we shall both increase women employment and support pre-school education."

"For 3 years, we shall not levy the social security premiums that are to be paid by the employer for women and for young people who are going to be employed for the first time."

However, in 2011 election manifesto, as in other election manifestos, the basis for social protection is that the preferred actor to ensure social protection shall be the family. By providing economic support to families that had to leave their children in the care of an institution due to poverty, the aim is to prevent the disruption of the family integrity due to economic status. Although the existence of supports that aim at family in the commitments can be explained by the conservative identity of the Justice and Development Party, this rationale is not enough. With the structuring of social protection system in Turkey in a generous manner and with the cost of the practices in healthcare, education, and social services, and in turn, with the absorption of this cost by the capital budget obligate diversity in the welfare providing actors. The structure of the family institution suffers as the state assumes the duty of social protection and the family loses its importance. At the same time, this situation means serious economic costs for the state. Thus, as in the other election manifestos, the 2011 election manifesto foregrounds commitments that focus on family, and this can be evaluated as being based on economics, along with the conservative approach that JDP employs. 
"Families shall be economically supported, and the necessary regulations shall be realized so as to prevent especially children to experience victimhood in the streets, nurseries and work environment, under abusive conditions, due to poverty and deprivation."

"We shall increase both the quantity and the quality of the current services, aids and supports to our children in need of protection, for them to become equal and protective individuals of our strong society in the future. Our goal here is to support our children in need of protection in warm, natural and social family environments that do not require protection in the first place."

In order to ensure the efficiency of social security, social assistance and social services within the body of the social protection, the efficiency of their implementation is important, along with their target audience, their quantity and their diversity. One of the conditions to ensure efficiency is the creation of a database and recording these services. Thereby, the communication of the responsible institutions with each other needs to be ensured, and the abuse of services, favoritism and loss of rights needs to be prevented. Especially the criticisms on the social assistance practices as being irregular and that they are not distributed based on rights are in turn criticized in the manifesto. The 2011 election manifesto commits to realize all practices with a database system.

"By moving into an electronic archive system, we shall offer faster retirement and healthcare transactions for our citizens."

"We shall realize the income assessment of our citizens without social security the premiums of which shall be covered by the state on the electronic medium by sharing data with the relevant institutions. Thereby, while completing the necessary transactions in a faster manner, we shall prevent irregularities and abuses."

"To resolve the problems of our workers that they face both in the field of work and the field of social security in the fastest manner and to offer better service to our workers and employers, we shall form a common database by ensuring coordination between institutions."

The commitment that social assistance and social services shall stop being on-demand but shall focus on submissions was first presented in the 2011 election manifesto. This system was called Family Social Support Programme 
(FSSP) and was shaped based on the understanding of personalized custom support, in which each individual's needs in a household should be identified via house visits. The goal here is to implement social assistance and social services based on rights, without creating deprivation, and in an efficient and productive manner. However, this commitment was implemented in a limited manner, and the later election manifestos still contained the commitments to widespread the FSSP system.

"We shall implement social support and service policies in compliance with the healthcare, employment, and education policies. In the field of social support and service, along with the healthcare, employment, and education services, we shall move into a household-based system within the framework of 'Family Social Support Programme'(FSSP) model."

"Within the scope increasing the efficiency of voluntary services and local governments in protective and preventive social services, we shall move into Family Social Support Programme (FSSP)."

"In the coming term, social support shall be provided simultaneously with social services. For example, while a family that has an individual with a disability will be offered social assistance, the necessary rehabilitation services shall be provided to the individual with a disability within the family, without the need for the family to apply for it. All these former and future practices shall ensure that the needs of the poor shall be identified and resolved in an up-close and personal manner."

"The status of the family shall be the basis in social supports. Instead of providing the same type and the same amount of aid to each family, the number of persons in the household, their ages and health conditions shall be taken into consideration. If there are persons in the family who can work, but are unemployed, they shall be directed to the labor force market."

The commitments that the social protection practices shall be implemented systematically via a database were often repeated in the 2011 election manifesto. This situation reveals that the aim here is to ensure and to increase the social assistance and social service activities that have achieved a sizable volume. As a response to the criticisms that the process of implementation of social assistance and social services is clientelist, partisan and ideological, the 
commitments contain a discourse stating that a social protection system based on rights shall be constructed in a transparent and an auditable manner.

"In order to implement the social support system efficiently and productively, the Integrated Social Assistance Services Project and Scoring Formula Project in collaboration with TUBITAK [Scientific and Technological Research Council of Turkey] and General Directorate of Social Assistance and Solidarity shall be concluded within a short amount of time. When this project is concluded, it shall ensure that the central database identifies the neediness status and their personal data of our citizens who have applied for social support and that all business and transactions regarding all social support and services are managed within unified norms and standards."

"We shall make the Interactive Social Service Delivery that shall ensure easy access to social services to all citizens become widespread."

"We shall ensure that all institutions that offer social services work in coordination."

In 2015, 2 general elections were held in Turkey, one on June 7 and one on November 1. In the election manifesto for the election to be held on June 7, 2014, several commitments were listed under the heading of "Social Policies." June manifesto comprises the shortest text amongst the election manifestos analyzed within the scope of this study and differs from other manifestos since it has the greatest number of headings in the field social policies but contains the least number of social policy commitments. Regarding social policy understanding, the commitment that each and every citizen shall be provided services based on the principles of equality and fairness, often repeated in all manifestos after 2002, is also emphasized in this manifesto.

"Our party that views the state as a tool to provide service to the people shall implement social policies that ensure wealth and happiness, not just for a class or group, but for all our citizens."

"It is obvious that a social state understanding ensuring that the state watches over the unemployed, poor, needy, sick and handicapped and ensuring that they live as it befits the human dignity is indispensable." 
In the manifesto, the target audience for social policy is defined as the elderly, the children, the unemployed, the needy, and the persons with a disability. It is significant that in the commitments, the content of the practices to be implemented for the target audience is not given and that these commitments are obscure. This situation shows that for the first time in an election, Justice and Development Party has not brought forth novel social policy commitments. On the other hand, the commitments for the persons with a disability are more concrete and extensive.

"Special programs for the poor, for old people who are in need of care, for children and for unemployed shall be formed and the citizens who face hardships shall not feel desolate and unattended."

"No one shall be allowed to feel discriminated due to their physical or mental handicap."

The commitment that the legs of social policy, namely social security, social assistance and social services shall be gathered under the roof of a single Ministry is of significance. It is expected that this commitment constitutes an integrity both from the aspect of the practicing actors and the beneficiaries in these three interconnected fields in the social protection system. The goal here is to form a social protection system in the household by considering all the needs of individuals within a household: the unemployment in the household shall be taken care of by social security; the old age, disability and the need for care shall be taken care of by social services; and in cases when socioeconomic fragilities are permanent, by social assistance. Within this context, it can be said that this commitment has been realized via Presidential Government System that entered into force on June 24, 2018. In this system, Ministry of Labor and Social Security was merged with Ministry of Family and Social Policies, and the Ministry of Family, Labor and Social Services was established. It should be noted that in order to observe how gathering social security, social service, and social assistance under the roof of one institution created a transformation from the productivity of aspect and efficiency of practices, impact analysis studies are required.

"For the purpose of ensuring common management of social security, social assistance, and social services, they shall be collected under the roof of a single ministry. Necessary measures shall be taken to ensure the unity of norms and 
standards in these institutions, to create the basic statistical data, to achieve actuarial balance and to utilize the assets in the most productive way."

One of the commitments for the social protection system is the healthcare service. Due to the appreciation of the transformation in healthcare since 2002 by the public, the commitments in this field have become indispensable in each election period. Social Security and General Health Insurance Law (GHI) that entered into force in 2006 has updated social security to encompass all citizens. ${ }^{2}$ Despite this practice, the ongoing practice has been offered as a commitment. Yet, solutions to the payment problem that occurs in GHI, especially since the time between the graduation of the young people and their entry into the work life is extended, did not find a place in the manifesto.

"Social security net shall be organized to encompass the whole population. The state must carry out basic health services for all, in collaboration with the private sector when necessary. An effective and high-quality healthcare system is indispensable for an advanced society."

"We shall move into a general health insurance system that shall encompass all of our citizens. Our party acknowledges that social security is a constitutional right and that ensuring each individual benefit from this right is a duty of the state. Therefore, within the scope defined by the constitution, a social security policy that befits the understanding of a social state shall be formed, and each individual shall be given a social security number."

Another issue of note in the manifesto is that instead of the term "person with a disability" the term "handicapped" is used in the commitments for the individuals with a disability. Pursuant to the amendment of April 25, 2013, it was accepted that instead of the phrases such as handicapped, cripple etc., the term "person with a disability" should be used. ${ }^{3}$ Despite this amendment, the term "handicapped" can be frequently found in the commitments.

Lastly, the election manifesto prepared for the general election held on November 1, 2015, is analyzed within the scope of this study. For the first time, the vote rate of JDP fell in the election held on June 7, 2015, and it was argued that this was due to the weak social policy commitments of JDP in the election campaign. Social policy commitments have an extensive place in the election

2 https://www.mevzuat.gov.tr/MevzuatMetin/1.5.5510.pdf

3 http://www.resmigazete.gov.tr/eskiler/2013/05/20130503-1.htm 
manifesto for the November 1, 2015, election that was disclosed to the public, revealing that this argument was accepted to be true. In this manifesto, social policies are explained under the heading of "Human Development and Advanced Society."

It was argued that the primary reason for decrease in the vote rates of the JDP, not the governing party on its own for the first time in the June 7, 2015, election, is that it could not develop a new discourse for its social policies. The commitments in the election manifesto prepared for the election of November 1,2015 , proves that this warning was heeded. The basic differences between the two manifestos are that manifesto prepared for June 7 election offers the ongoing practices as commitments, talks about the problems, but not of the accomplishments of the JDP period, and does not contain concrete commitments. By contrast, November 1 manifesto foregrounds concrete commitments. Another difference is that whereas in the November 1 manifesto, it is claimed the deeds of the previous term are a success, there are also concrete commitments proposed to resolve the problems of practices in the current circumstances. However, as in the former manifesto, this manifesto again uses the phrase "handicapped" instead of "person with a disability".

Regarding the social policy understanding, this manifesto uses similar statements to those of the other manifestos. Again, the understanding of "Let man flourish and the State will also flourish" was emphasized in this manifesto, and the equal opportunity and social justice were put forth as goals. As a difference, this manifesto also makes use of the terms "very high human development" and "human development". It can be said that there is a change in the social policy understanding, that instead of assessing the social policy practices as temporary solutions and costs, they shall be constructed as long-term permanent solutions. The commitment is to adopt another approach in which social policy practices are to be accepted not as costs, but as an investment tool.

"Amongst the basic priorities of JDP governments are the policies and practices that aim directly at humans and society. Our party adopts the maxim 'Let man flourish and the State will also flourish.','

"We, as JDP, have our roots in an understanding that observes human as the most honorable of the created. For us, each human is valuable, and we are responsible to each and every human. With this idea in our minds, we have put 
humans to the center of all our policies. We are defining our economic and social policies within the framework of our understanding of our human development that prioritizes social justice."

"While seeing our children as potential youth and our youth as the assurance of our future, we shall ensure the physical, cultural and artistic environment that they deserve with higher quality, and thus continue our understanding of development that puts human to the center. With this understanding, we aim to move Turkey from the category of countries with 'high human development' to 'very high human development' category."

Regarding social protection practices, the manifesto includes concrete commitments. It was stated that the home healthcare services that commenced in 2014, despite the risk of repeat practice (since they were offered both by ministry and municipalities), shall be provided in coordination between these two institutions. This commitment is also an indicator of the transition into a process in which efficiency and productivity of social policy practices are given importance. Since 2002, the number of citizens benefiting from social policies and the increase in the number of resources transferred to these citizens constitute the success story. However, this success story comes at an economic cost. Therefore, the quantitative increase should be directly proportional to the qualitative growth. Hence, it is observed that the understanding that focuses on the increase in quality is foregrounded, and this is also reflected in the social policy commitments. In the same manner, the statement that the aim is the inclusion of the citizens who benefit from the offered services into the economic and social life reflects the paradigm shift in the social policy practices. Family and Social Support Programme (FSSP) that was not put into practice, despite being present in the former manifestos, is foregrounded in this manifesto as an important practice to ensure efficiency and productivity in social assistance and social services.

"We shall develop self-care at home services by integrating home healthcare services with the Ministry of Family and Social Policies and municipalities."

"We shall ensure that the services offered at social service unit and the participation of the family members to economic and social life are increased. We shall complete the infrastructure of Family Social Support Programme (FSSP) that shall reach out to all our citizens that need social assistance or 
social service, establish an informatics infrastructure, and by employing adequate number of qualified staff, gradually realize FSSP."

In contrast with the former manifesto, the advantages of the comprehensive system ensured by GHI are explained in this manifesto under the social security heading, along with the commitments that shall provide solutions to the problems arising under current conditions. The manifesto talks not just about the scope of the services, but at the same time about starting a fair process that shall ensure the continuity of the system.

"While including all of our citizens within the social security and general health insurance, at the same time, we are aiming at forming a social security system that is sustainable and effective. Our basic principle in developing our social security system is to create a fair and sustainable balance between employees, employers, and pensioners."

"As JDP, we shall continue to establish progress in the field of social security in the coming term and update the system by closely following the changing conditions and developing standards in the world."

Regarding the social assistance, one of the most controversial social policy practices implemented in JDP Period, there are commitments to create the link between social assistance and employment. Instead of the term "social assistance", "social support" is used, and the manifesto commits to support the employer in the cases when those who benefit from social assistance begin to be employed. This commitment has turned into a practice following the election.

"We shall increase the efficiency and the productivity of the system by reevaluating the income test system applied within the scope of General Health Insurance and the related general health insurance premium payments. If they are employed, we shall pay the insurance premiums of our citizens who receive social support as a support to the employer."

This manifesto also offers commitments on women employment and familyfriendly social policies within the scope of social protection. Since women labor force ratio varies within the range of 20-30 percent in Turkey, the importance of the social state practices in this field has increased. The primary reason that women in Turkey give a break to their work life or quit is their 
family responsibilities. On the other hand, slowing population increase rate and the decreasing number of children reveal that Turkey's young population structure shall be changed in medium and long terms. In the election manifesto, within the social security commitments regarding women employment, JDP foregrounds the efforts for the reconciliation of motherhood and work life. In the same manner, JDP commits to spread kindergartens as a solution for the childcare -the working mothers' greatest issue. This situation reveals that to prevent the women from being forced to choose between employment and family life, JDP, a party that has a conservative identity, adopts practices of reconciliation of work, home, and family life, in a manner similar to that of a social democratic welfare regime.

"In order to strengthen the childbirth leaves and rights of workers, we shall make the necessary amendments in the Civil Servants Law and the Labor Law."

"We shall make amendments to harmonize the childbirth leaves and rights of our civil servants with those of workers who are subject to Labor Law. We shall realize regulations to incentivize the establishment of kindergartens to spread high-quality, affordable and easy to access kindergarten options."

When the social policy sections and chapter headings of five election manifestos are analyzed, it is observed that there are commitments about social security, education, and healthcare in each election year and that the social policy target audience, i.e., family, women, youth, children, persons with disability, and poor individuals, are given place in the social policy commitments (see Table 1). In its social policy understanding, Justice and Development Party constantly emphasizes "justice", and this emphasis is supported by the commitments to ensure the voters benefit from welfare services in an equal and fair manner, independent of their socioeconomic status. The manifestos state that the citizens who are weak from the aspect of socioeconomic indicators and in need of support, i.e., the poor, the persons with a disability, the elderly etc., shall be supported by the state. The emphasis on the reason for this support not being party based, but as a prerequisite of "social state" increases after the 2007 election manifesto. In addition, a social protection system that encompasses social security, social services, and social assistance is an unchanging commitment in the election manifestos of Justice and Development Party. After 2011, in order to render the costs of social protection sustainable, a paradigm shift in the social policy understanding is observable, and this paradigm exhibits 
itself concretely in the terms of efficiency, productivity, and high human development.

Table 1

Social Policy Headings in the Election Manifestos of Justice and Development Party within the 2002-2015 Period

\begin{tabular}{|c|c|c|c|c|c|}
\hline & \multicolumn{5}{|c|}{ Year } \\
\hline & 2002 & 2007 & 2011 & June 7, 2015 & $\begin{array}{c}\text { November 1, } \\
2015\end{array}$ \\
\hline $\begin{array}{l}\text { Social } \\
\text { Policy } \\
\text { Chapter in } \\
\text { the Election } \\
\text { Manifesto }\end{array}$ & Social Policies & $\begin{array}{l}\text { Strengthening } \\
\text { the Social } \\
\text { Structure }\end{array}$ & $\begin{array}{l}\text { Strong Civil } \\
\text { Society }\end{array}$ & Social Policies & $\begin{array}{c}\text { Human } \\
\text { Development } \\
\text { and Advanced } \\
\text { Society }\end{array}$ \\
\hline \multirow{7}{*}{ Headings } & $\begin{array}{l}\text { Family, Women } \\
\text { and Youth }\end{array}$ & $\begin{array}{l}\text { Family, } \\
\text { Women, } \\
\text { Youth and } \\
\text { Elderly }\end{array}$ & Family & $\begin{array}{c}\text { Family and } \\
\text { Social Services }\end{array}$ & $\begin{array}{c}\text { Family, } \\
\text { Children and } \\
\text { Dynamic } \\
\text { Population }\end{array}$ \\
\hline & $\begin{array}{l}\text { Social Security } \\
\text { for Everyone }\end{array}$ & $\begin{array}{c}\text { Social } \\
\text { Security }\end{array}$ & Social Security & Social Security & $\begin{array}{c}\text { Social } \\
\text { Security }\end{array}$ \\
\hline & $\begin{array}{l}\text { Quality } \\
\text { Education }\end{array}$ & Education & Education & Education & $\begin{array}{l}\text { Quality } \\
\text { Education }\end{array}$ \\
\hline & Healthy Society & Health & Health & Health & $\begin{array}{c}\text { Healthy } \\
\text { Generations }\end{array}$ \\
\hline & $\begin{array}{l}\text { Prevention of } \\
\text { Unemployment }\end{array}$ & Work Life & & Work Life & Work Life \\
\hline & & Youth & Youth & $\begin{array}{l}\text { Youth and } \\
\text { Sports }\end{array}$ & Youth \\
\hline & $\begin{array}{c}\text { Our } \\
\text { Handicapped } \\
\text { Citizens }\end{array}$ & $\begin{array}{c}\text { The } \\
\text { Handicapped }\end{array}$ & $\begin{array}{c}\text { Our Citizens } \\
\text { with a } \\
\text { Disability }\end{array}$ & & \\
\hline
\end{tabular}




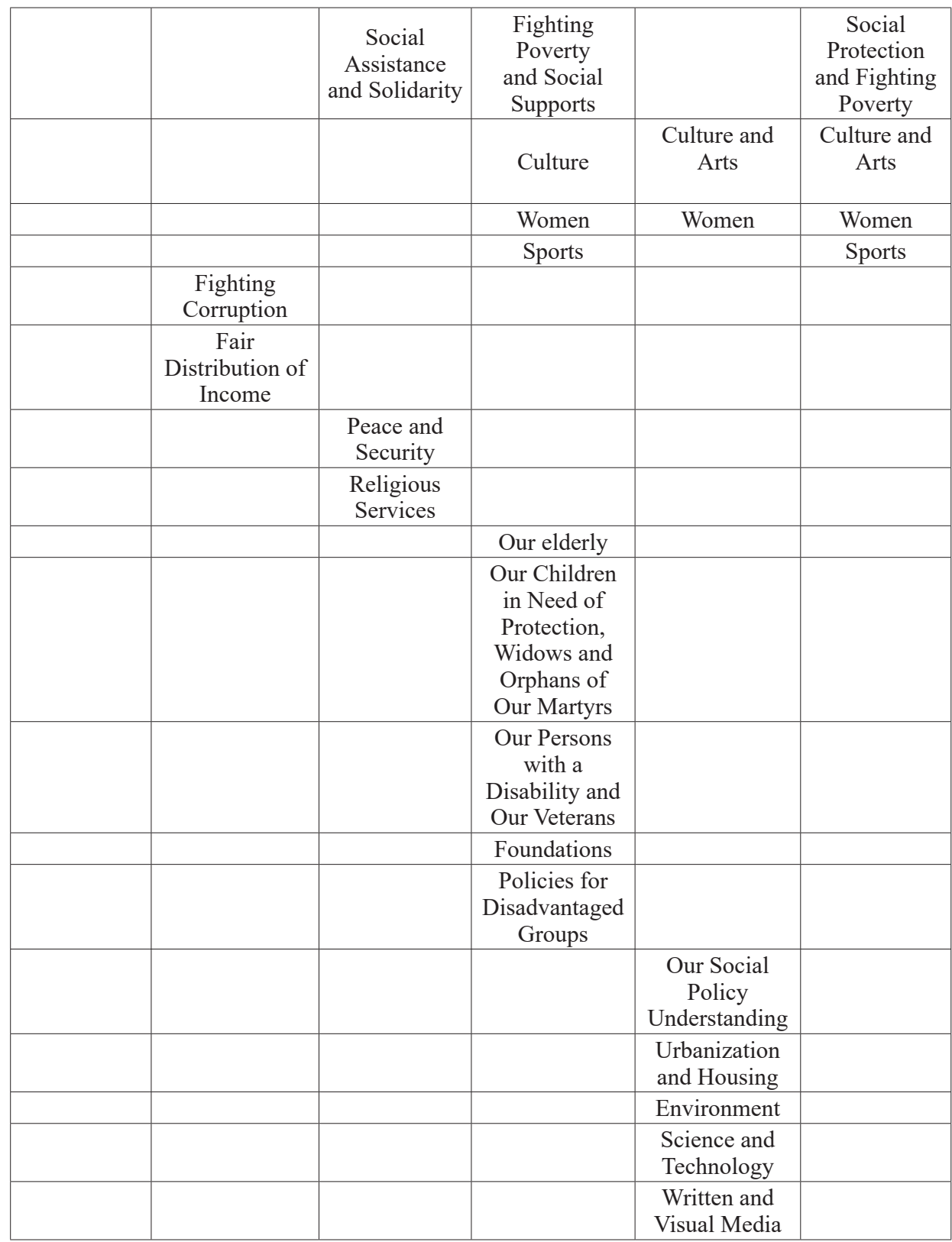

Source: The table was created by the author in light of the 2002, 2007, 2011, June 7, 2015 and November 1, 2015 Election Manifestos of the Justice and Development Party. 


\section{Discussion and Conclusion}

Social policies are used to allow disadvantaged groups in society to participate in social and economic life. While social policies vary from country to country based on their social, economic, and political structure, there are also differences in their implementation based on the welfare typology that they adopt. These policies have been referred in Turkey since 2003, due to its politics and its political environment, and they are of particular interest to the voters as they encompass subjects, such as fair distribution of income, social protection, support to disadvantaged individuals, access to welfare services by every citizen (irrespective of their social status) etc. The accepted view that social policies have an impact on voting behavior is reflected in the election manifestos after 2002. It is argued that social policies have an impact on the election success of Justice and Development Party, the party with the most votes in five general elections in the period between 2002-2015. This study analyzes the election manifestos prepared by Justice and Development Party for five general elections within a 13-year duration and attempts to comprehend the social policy understanding of the party and the guiding principle in its social protection system.

With the impact of the economic crisis experienced before the general election held on November 3, 2002, the election manifesto of JDP in 2002 contains the commitment to reduce poverty and to handle the social policies in an integrated manner. During an economic crisis in a country, the first field to suffer from cutbacks is the field of social policies. When the year 2002 is taken into consideration, despite the fragile economic structure in Turkey, the commitment in JDP manifesto is to ensure that the state shall not give up on social policies, so that the citizens do not feel desperate. In the commitments that reflect the social policy understanding, the terms used are "social justice" for 2007 election; "equal opportunity" for 2011 election; "equality and justice" for the election held on June 7, 2015; and "justice and human development" for the election held on November 1,2015. Since these terms cannot be though independent of one another, it can be argued from the aspect of social policy understanding of the party that the election manifestos are disclosed to the voters with the principle of "equal citizenship." The commitments in the election manifestos to create a common database for social security, social assistance, and social services -the components of social protection system- started in 
2007. The terms of common database, coordination, and collaboration, expressed in different terms in all the later election manifestos, show that efficiency is gaining importance in the social protection system. However, it is also apparent that the concrete steps to be taken in this issue were either delayed or postponed with the existence of the commitment regarding FSSP in the election manifesto for the election to be held on November 1, 2015.

The commitments regarding finance and sustainability in social security, human development and FSSP prove that qualitative increase, along with quantitative increase in the social protection system came into prominence. This paradigm shift can be interpreted as the beginning of the adoption of a new policy that does not observe social policy practices as costs. Instead, each and every citizen having access to welfare services is seen as investments to the human capital of the country. Addition of social policies heading to the indispensable subject headings of political parties, such as economy, law, and foreign policy reveals that this field provides a gain for the political parties. For the first time in its history, the vote rates of Justice and Development Party decreased in the election held on June 7, 2015, and it was argued that one of the primary reasons for this decrease was its weak social policy commitments. Therefore, it can be argued that the observation that social policies influence voter behavior is an accepted view. While the election manifestos of JDP have social security, education, and health as common social policy subjects, social policies aiming at women, youth, children, persons with a disability, and elderly population find a place in every manifesto, too. While in the election manifestos of JDP, its conservative party identity is reflected in its family-oriented social policies, its commitments regarding social supports for the women participation to employment and commitments to provide kindergartens and housing for single-parent families display characteristics similar to those of social democratic welfare typology.

\footnotetext{
Hakem Değerlendirmesi: Dış bağımsız.

Çıkar Çatışması: Yazar çıkar çatışması bildirmemiştir.

Finansal Destek: Yazar bu çalışma için finansal destek almadığını beyan etmiştir.

Peer-review: Externally peer-reviewed.

Conflict of Interest: The author have no conflict of interest to declare.

Grant Support: The author declared that this study has received no financial support.
} 


\section{References}

Alp, H., Turan, E. (2018). Comparative analysis of political parties' digital technology and innovation policies in the general elections declarations of June 24, 2018. Journal of Social and Humanities Sciences Researches, 5(23), pp. 1068-1077.

Altiok, M. (2007). The last phase in the neo-liberal structural adjustment process: AKP government. Society and Democracy, 1(1), 57-72.

Arklan, Ü., Tanac1, F. (2020). An outlook on election campaigns in the context of declarations: A comparative analysis on the local elections of March 31, 2019. Suleyman Demirel University Visionary Journal, 11(26), pp. 1-29.

Aydoğan, A., Slapin, J. B. (2015). Left-right reversed: Parties and ideology in modern Turkey. Party Politics, 21(4), pp. 615-625.

Aytaç, S. E. (2017). Policy priorities in the election manifestos of political parties in Turkey, 2002-2015. Journal of Political Sciences, 26(2), pp. 7-26.

Beriş, H. E. (2011). JDP 2007-2011 election manifestos: Continuity and change. $H$. Turşucu and H. E. Beriş (Ed.) Political Academy, 10, 109-141.

Bulut, P., Güven, S., (2010). Primary education in political parties' programs. Journal of Theory and Practice in Education, 6(2), pp. 281-300.

Çelik, A. (2010). Conservative social policy orientation: Charity instead of right-charity instead of obligation. Istanbul University Journal of the Faculty of Political Sciences, $42,63-81$.

Doğan, A. (2016). The effect of social assistance on the political choices of the poor: A study on the urban poor. Selcuk University Faculty of Communication Academic Journal, 9 (3), 69-89.

Durmaz, O. S. (2016). Establishment of the neo-liberal social policy regime and the AKP. Work and Society, 1, 143-167.

Ekici, S. and Acar, A. (2021). Evaluating election declarations of the ruling and the main opposition parties in Turkey in terms of gender inequality. Journal of Ahi Evran University Institute of Social Sciences, 7(1), pp. 287-306.

Gökçe, O., Akgün, B., Karaçor, S. (2002). Anatomy of the November 3rd elections: Continuity and change in Turkish politics. Selcuk University Faculty of Economics and Administrative Sciences Journal of Social and Economic Research, 2 (4), 1-44.

Güneş, M. (2012). Sustainability of social assistance as a public administration policy in combating poverty. Journal of Social and Economic Research, 12(24), 149-184.

Gürbüz, S., Şahin, F. (2014). Research Methods in Social Sciences, Istanbul: Seçkin Publications.

Kapar, R. (2015). Social Aid in AKP Rule. Koray, M. (Ed.), Politeness, Nature, Market, Social Policy in the AKP Era, Istanbul: İletişim Publications. 
Özipek, B. B. (2011). Justice and Development Party (AK Party) Period Domestic and Foreign Policy (2002- ..). Çaylak, A., Dikkaya, M., Göktepe, C., Kapu, H. (Eds.), The Political History of the New Millennium to Turkey from the Ottoman Empire, Ankara: War Publications.

Özkaynar, K. (2015). The prospect of declaration of 2011 and 2015 elections of the political parties: A document review and content analysis study. The Journal of Academic Social Science, 3(17), pp. 439-452.

Özsoy, O. (2002). Voting Behavior and Effective propaganda in Turkey, Istanbul: Alpha Broadcasting Press.

Sakal, M. (1998). Actors involved in the political decision-making process and their roles.

9 Eylul University Faculty of Economics and Administrative of Journal, 13(1), 215-226.

Sayın, U. and Gümüş, S. S. (2016). The evaluation to political parties' election declarations in the June 7th 2015 parliamentary general elections on the basis of the content of the disability. Toplum ve Demokrasi, 10 (21), January-June, pp. 69-89.

Şeşen. E., Ertürk, K. (2017). Reflections of the post-1990's environmental policies to the election statements in Turkey. Selcuk Communication, 10(1), pp.188-215.

Tan, A., Baydaş, A. (2017). The effects of voter characteristics on voting behavior. Igdir University Journal of Social Science, Issue:13

Terkan, B. (2013). Political parties' discourses and policies concerning woman (The cases of AKP and CHP). Selcuk Communication, 6(2), pp. 115-136.

Tok, T. N. (2012). Education discourses and policies of political Parties in Turkey. Educational Administration: Theory and Practice, 18(2), pp. 273-312

Urhan, G., Urhan, B. (2015). Social Aid in the AKP Period. Koray, M. (Ed.), Politeness, Nature, Market, Social Policy in the AKP Era, Istanbul: İletişim Publications. 